\title{
VALIDASI BIG FIVE INVENTORY-2 (BFI-2) UNTUK INDONESIA: BELUM SEMPURNA TETAPI VALID DAN RELIABEL MENGUKUR KEPRIBADIAN
}

\author{
Awaludin Ahya \& Ide Bagus Siaputra \\ Fakultas Psikologi, Universitas Surabaya, Jln. Raya Kalirungkut, Surabaya, 60293, Indonesia \\ Korespondensi: std@staff.ubaya.ac.id
}

\section{VALIDATION OF BIG FIVE INVENTORY-2 (BFI-2) FOR INDONESIAN: NOT PERFECT BUT STILL VALID AND RELIABLE TO MEASURE PERSONALITY}

\begin{abstract}
The Big Five Inventory-2 (BFI-2) is the latest version of the personality measurement too according to the theoretical framework of the five-factor model. This study aims to replicate the validity of the BFI-2 test in the Indonesian version. The validity test related to internal structures were conducted using Principal Component Analysis (PCA) and Confirmatory Factor Analysis (CFA), while convergent validity was generated through correlation with BFI1. The respondents was 853 students from several state and private universities in North Sumatra and East Java. Online data collection was conducted using Google Form. The results of the PCA showed that 50 items (83\%) of the Indonesian version of BFI-2 have an adequate loading factor to the related dimensions. The results of the CFA on the facet level model have a better fit index than the dimension level, meaning that these findings support the facet level measurement model of BFI-2 Indonesia. The five dimensions of Indonesia's BFI-2 have positive correlations with the BFI-1 dimension at a moderate level. Thus, it showed that Indonesia's BFI-2 is proven to be converging with BFI-1.
\end{abstract}

Manuscript type: Original Research

Article history:

Received 12 February 2021

Received in revised form 29 April 2021

Accepted 20 May 2021

Available online 1 November 2021

\section{Keywords:}

Big Five Inventory-2

big five personality

translation

\begin{abstract}
Abstrak
Big Five Inventory-2 (BFI-2) merupakan versi terbaru dari alat ukur kepribadian menurut kerangka teori five factor model. Penelitian ini bertujuan untuk mereplikasi pengujian validitas BFI-2 pada versi Bahasa Indonesia. Uji validitas terkait struktur internal dilakukan menggunakan Principal Component Analysis (PCA) dan Confirmatory Factor Analysis (CFA), sedangkan validitas konvergen melalui korelasi dengan skor BFI-1. Responden adalah 853 mahasiswa dari beberapa Perguruan Tinggi Negeri dan Swasta di Sumatra Utara dan Jawa Timur. Pengumpulan data secara online menggunakan Google Form. Hasil analisis PCA menunjukkan sebanyak 50 butir (83\%) BFI-2 versi Indonesia memiliki muatan faktor memadai terhadap dimensi terkait. Hasil analisis CFA pada model level faset memiliki indeks fit yang lebih baik daripada level dimensi, artinya temuan ini mendukung model pengukuran faset pada BFI-2 Indonesia. Kelima dimensi BFI-2 Indonesia memiliki korelasi positif dengan dimensi BFI-1 pada tingkat moderat, sehingga temuan ini menunjukkan bahwa BFI-2 Indonesia terbukti konvergen dengan BFI-1.
\end{abstract}

Kata Kunci: Big Five Inventory-2, big five personality, penerjemahan

\section{Dampak dan Implikasi dalam Konteks Ulayat}

Penelitian ini merupakan seri replikasi dari pengujian validitas alat ukur Big Five Inventory-2 (BFI-2) pada beberapa konteks bahasa dan budaya. Penelitian ini menyediakan BFI-2 versi Bahasa Indonesia beserta pelaporan properti psikometrisnya. Hasil penelitian ini menunjukkan bahwa alat ukur BFI-2 versi Bahasa Indonesia terbukti valid dan reliabel dalam mengukur kepribadian sesuai dengan teori Big Five Personality. Alat ukur ini dapat digunakan sebagai instrumen dalam studi eksplorasi lebih lanjut (melalui penelitian lanjutan) terkait topik kepribadian pada konteks Bahasa Indonesia, sehingga akumulasi hasil penelitian maupun komunikasi sistematis di antara peneliti kepribadian di lintas budaya dapat dilakukan. 


\section{PENDAHULUAN}

Salah satu alat ukur kepribadian dengan paradigma sifat (trait) yang banyak dikenal saat ini adalah Big Five Inventory (BFI) (Usslepp dkk., 2020). BFI memiliki konsepsi teoretis yang cukup lengkap dan luas dari sejarah pengembanganya (Denissen dkk., 2020; Soto \& John, 2017). Pada mulanya, BFI dikembangkan melalui metode leksikal dan memperoleh sebanyak 300 deskripsi kata atau frasa yang mewakili sifat kepribadian secara universal (Soto \& John, 2017). Para ahli kepribadian berupaya meringkas dan menyederhanakannya hingga akhirnya menemukan lima dimensi utama pada alat ukur BFI (Soto \& John, 2017).

Hasil penelitian dengan tema dan topik mengenai struktur BFI sudah banyak dilaporkan pada beberapa konteks budaya, serta diterjemahkan dalam beberapa bahasa (Soto \& John, 2017). Kesimpulan umum dari hasil beberapa studi tersebut menyatakan bahwa BFI mendukung untuk dilakukan generalisasi dalam berbagai bahasa dan budaya (John dkk., 2008). Dari serangkaian studi tersebut didapati bahwa label pada dimensi Big Five Personality diberi nama yang bervariasi (Denissen dkk., 2020). Hal ini mengakibatkan alat ukur BFI memiliki konsep yang mungkin tumpang tindih dengan konsep lainnya yang semestinya tidak memiliki relevansi dengan konsep teorinya (Vedel dkk., 2021). Selain itu, ditemukan pula "perluasan” konsep pada dimensi-dimensi BFI, yakni pada area definisi dan objek (atribut ukur) yang kurang sesuai dari konsep awalnya. Contohnya, dimensi kehati-hatian (conscientiousness) memiliki area definisi yang lebih luas dalam menjelaskan sejumlah perilaku yang tidak semestinya diprioritaskan oleh dimensi ini, seperti kerapian, sifat gigih, dan ketelitian (Soto \& John, 2017). Perluasan konsep dan objek ukur yang ditemukan umumnya akan berpengaruh terhadap hasil asesmen dari alat ukur yang mungkin kurang tepat dalam memprediksi kepribadian individu (John dkk., 2008).

Sebagai salah satu dari alat ukur yang paling banyak digunakan dalam penilaian kepribadian (Denissen dkk., 2020), BFI versi terbaru mulai dikembangkan dan diberi nama Big Five Inventoy-2 (BFI-2). Berbeda dengan BFI-1, model pengukuran (konstruk) BFI-2 menggunakan model hierarki, ketika atribut kepribadian tidak hanya diukur di level dimensi melainkan hingga level faset (Vedel dkk., 2019). Faset merupakan sebuah sumber variasi yang muncul dari sebuah pengukuran dan memiliki kemiripan dengan "faktor" yang digunakan dalam analisis varian (John dkk., 2008).). Faset dapat mencakup berbagai keberagaman indikator kepribadian, sehingga pengukuran level faset akan lebih spesifik dalam memberikan informasi mengenai kepribadian (John dkk., 2008). Faset pada alat ukur BFI-2 dirancang melalui pertimbangan teoretis dan hasil penelitian empiris terkait BFI yang 
sudah dilakukan sebelumnya (Soto \& John, 2017). Alat ukur BFI-2 memiliki struktur yang terdiri dari tiga faset, dengan salah satu fasetnya adalah faset kunci (utama) sebagai manifestasi dari dimensi aslinya, misalnya faset supel (sociability) untuk dimensi kesukaan terhadap hal di luar diri (extraversion). Sementara itu, dua faset lainnya sebagai indikator kepribadian yang memiliki kebermaknaan secara teoretis dan konsisten pada temuan penelitian sebelumnya mengenai konsep teori dari Big Five Personality, yaitu faset asertif atau ketegasan (assertiveness) dan semangat (energy level) secara teoretis merupakan indikator dari dimensi kesukaan terhadap hal di luar diri (Soto \& John, 2017). Model hierarki dalam pengukuran BFI bukanlah hal yang baru, sebelumnya telah ada alat ukur BFI post hoc yang juga menggunakan model hierarki. Selain itu, konsep awal BFI juga mementingkan kontribusi level faset dalam struktur pengukurannya (Soto \& John, 2017).

Beberapa temuan menunjukkan bahwa faset pada BFI dapat memprediksi varian tambahan yang secara teoretis memiliki hubungan dengan kepribadian (Denissen dkk., 2020), misalnya Penelitian MacCann dkk. (2009) melaporkan bahwa nilai tes Scholastic Aptitude Test (SAT) dari siswa tingkat menengah mampu diprediksi lebih baik oleh faset dari dimensi kehati-hatian, yakni perfeksionisme (perfectionism), serta tingkat ketidakhadiran (absenteesm) yang rendah pada pekerjaan dapat diprediksi lebih baik oleh faset ketekunan (industriousness). Bleidorn dkk. (2013) melaporkan bahwa hubungan antara dimensi kenegatifan emosi (negative emotionality) dan eksplorasi identitas (identity-exploration) mampu diprediksi oleh faset internalisasi emosi negatif, misalnya: kecemasan (anxiety), depresi (depression), dan kelabilan emosi (emotional volatility).

Selama lebih dari 20 tahun terakhir, alat ukur BFI sudah diteliti dan digunakan dalam sejumlah penelitian (Denissen dkk., 2020), tetapi BFI tidak terlepas dari bias respons. Salah satu bias respons dalam BFI yang ditemukan cukup sistematis berpengaruh terhadap validitasnya adalah bias kesetujuan (acquiescence) (John dkk., 2008). Bias kesetujuan merupakan kecenderungan untuk secara konsisten memilih menyetujui (setuju; memilih iya) maupun memilih tidak menyetujui pada pilihan yang terdapat pada butir kuesioner terlepas dari isinya (Soto \& John, 2017). Untuk mengontrol data dengan pola respons kesetujuan, pengembangan alat ukur BFI-2 melakukan analisis dwifaktor (bifactor), yakni dengan menambahkan variabel laten pada model pengukuran. Variabel laten ini dapat mengontrol pola jawaban kesetujuan. BFI-2 juga dirancang memiliki jumlah butir favourable dan unfavourable yang seimbang pada 15 fasetnya, keseimbangan jumlah butir ini secara teoretis juga dapat mereduksi bias kesetujuan (Soto \& John, 2017).

Sejauh ini, pengujian properti psikometrik alat ukur BFI-2 yang sudah dilaporkan meliputi: 1). validitas struktur internal melalui uji model dengan analisis faktor konfirmatori; 2). konsistensi 
internal (internal consistency); 3). validitas hubungan dengan variabel (alat ukur) lain; dan 4). validitas diskriminan level faset. Pelaporan hasil penelitian penerjemahan BFI-2 pada beberapa bahasa yang sudah dilakukan dapat dilihat pada Tabel 1.

Melalui Tabel 1 dapat diketahui beberapa pelaporan hasil penelitian alat ukur BFI-2 dalam beberapa konteks bahasa. Berdasarkan hasil beberapa penelitian tersebut, dapat diketahui bahwa BFI2 memiliki laporan properti psikometrik yang cukup lengkap. Sejauh ini, penelitian dengan tema validasi dan penerjemahan alat ukur BFI-2 pada konteks Bahasa Indonesia masih belum ada, oleh karena itu tujuan penelitian ini adalah melakukan penerjemahan dan uji validitas alat ukur BFI-2 versi Bahasa Indonesia. Pengujian validitas dan prosedur analisis pada penelitian ini mereplikasi penelitian Soto dan John (2017). Uji validitas penelitian ini meliputi: 1). pengujian struktur internal BFI-2 pada tingkat dimensi melalui Principal Component Analysis (PCA); 2). pengujian model struktur pengukuran tingkat faset melalui Confirmatory Factor Analysis (CFA); dan 3). validitas konvergen dengan alat ukur BFI-1. Dengan demikian, maka perumusan hipotesis penelitian ini adalah sebagai berikut:

$\mathrm{H}_{1}$ : Butir BFI-2 Indonesia memiliki loading factor $(\mathrm{PCA}) \geq .4$ pada dimensi teoretisnya.

$\mathrm{H}_{2}$ : Faset-faset BFI-2 memiliki loading factor $\geq .4$ pada dimensi teoretisnya.

$\mathrm{H}_{3}$ : Model struktur pengukuran BFI-2 memiliki kesesuaian berdasarkan 3 kriteria fit.

$\mathrm{H}_{4}$ : Dimensi BFI-2 Indonesia memiliki korelasi positif dengan dimensi BFI-1 Indonesia.

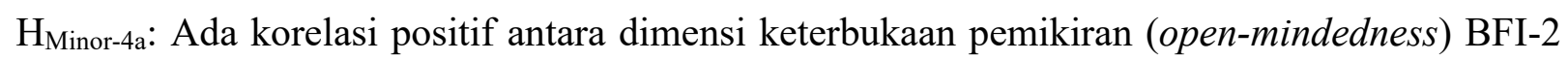
dengan dimensi keterbukaan (openness) BFI-1.

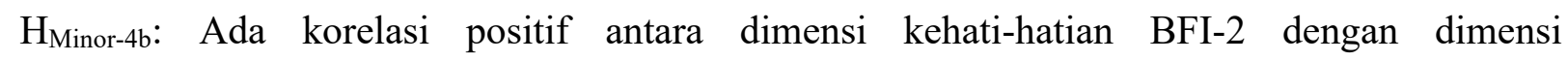
conscientiousness BFI-1.

$\mathrm{H}_{\text {Minor-4c: }}$ Ada korelasi positif antara dimensi kesukaan terhadap hal di luar diri BFI-2 dengan dimensi ekstraversi BFI-1.

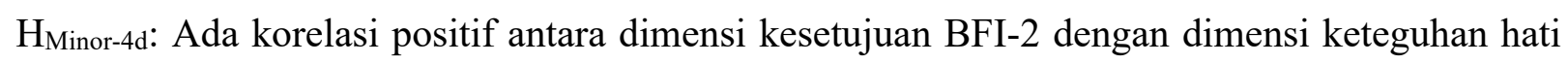
BFI-1.

HMinor-4e: Ada korelasi positif antara dimensi kenegatifan emosi BFI-2 dengan dimensi neurotisisme (neuroticism) BFI-1. 
Tabel 1.

Daftar Beberapa Penelitian Penerjemahan Alat Ukur BFI-2

\begin{tabular}{|c|c|c|c|c|}
\hline & Judul & $\begin{array}{l}\text { Bahasa/ } \\
\text { Negara }\end{array}$ & Penulis (tahun) & Hasil Penelitian \\
\hline 1. & $\begin{array}{l}\text { The next Big Five Inventory } \\
\text { (BFI-2): Developing and } \\
\text { assessing a hierarchical model } \\
\text { with } 15 \text { facets to enhance } \\
\text { bandwidth, fidelity, and } \\
\text { predictive power. }\end{array}$ & $\begin{array}{l}\text { Inggris/ } \\
\text { Amerika }\end{array}$ & $\begin{array}{l}\text { Soto dan John } \\
\text { (2017) }\end{array}$ & $\begin{array}{l}\text { 1. Validitas struktur dimensi }(60 / 100 \% \\
\text { butir BFI-2 memiliki nilai loading PCA }> \\
\text {.30). } \\
\text { 2.Validitas konvergen }(r>.5 \text { dengan } \\
\text { BFI-1, Mini Markers, BFAS, NEO-PI-R, } \\
\text { dan NEO-FFI). } \\
\text { 3. Reliabilitas konsistensi internal (rata- } \\
\text { rata Cronbach's Alpha }=.87) \text {. } \\
\text { 4. Reliabilitas test-retest (test }=.87 \text {; retest } \\
=.80) .\end{array}$ \\
\hline & $\begin{array}{l}\text { Development and validation of } \\
\text { the Danish Big Five Inventory- } \\
\text { 2: Domain-and facet-level } \\
\text { structure, construct validity, } \\
\text { and reliability. }\end{array}$ & $\begin{array}{c}\text { Denmark/ } \\
\text { Denmark }\end{array}$ & $\begin{array}{l}\text { Vedel dkk. } \\
\text { (2019) }\end{array}$ & $\begin{array}{l}\text { 1. Validitas struktur dimensi }(60 / 100 \% \\
\text { butir BFI-2 memiliki nilai loading PCA }> \\
.30) \text {. } \\
\text { 2. Validitas konvergen }(r>.50 \text { dengan } \\
\text { Mini Markers). } \\
\text { 3. Reliabilitas konsistensi internal (rata- } \\
\text { rata Cronbach's Alpha }=.89) . \\
\text { 4. Reliabilitas test-retest }(\text { test }=.89 ; \text { retest } \\
=.89) \text {. }\end{array}$ \\
\hline & $\begin{array}{l}\text { The Big Five Inventory-2: } \\
\text { Replication of psychometric } \\
\text { properties in a Dutch } \\
\text { adaptation and first evidence } \\
\text { for the discriminant predictive } \\
\text { validity of the facet scales. }\end{array}$ & $\begin{array}{l}\text { Belanda/ } \\
\text { Belanda }\end{array}$ & $\begin{array}{c}\text { Denissen } \\
\text { dkk. (2020) }\end{array}$ & $\begin{array}{l}\text { 1. Validitas struktur dimensi }(60 / 100 \% \\
\text { butir BFI-2 memiliki nilai loading PCA }> \\
.30) \text {. } \\
\text { 2. Validitas konvergen }(r>.50 \text { dengan } \\
\text { IPIP). } \\
\text { 3. Reliabilitas konsistensi internal (rata- } \\
\text { rata Cronbach's Alpha }=.86) .\end{array}$ \\
\hline & $\begin{array}{l}\text { Validation of the short and } \\
\text { extra-short forms of the Big } \\
\text { Five Inventory-2 (BFI-2) and } \\
\text { their German adaptations. }\end{array}$ & $\begin{array}{l}\text { Jerman/ } \\
\text { Jerman }\end{array}$ & $\begin{array}{l}\text { Rammstedt dkk. } \\
\text { (2018) }\end{array}$ & $\begin{array}{l}\text { 1. Validitas struktur dimensi }(15 / 100 \% \\
\text { butir BFI-2XS memiliki nilai loading } \\
\text { PCA }>.30) \text {. } \\
\text { 2. Validitas konvergen }(r>.5 \text { dengan } \\
\text { NEO-PiR). } \\
\text { 3. Reliabilitas konsistensi internal (rata- } \\
\text { rata Cronbach's Alpha }=.95) \\
\text { 4. Reliabilitas test-retest BFI XXS (test }= \\
.53 ; \text { retest }=.73) .\end{array}$ \\
\hline 5 & $\begin{array}{l}\text { Slovak Adaptation of the Big } \\
\text { Five Inventory (BFI-2): } \\
\text { Psychometric Properties and } \\
\text { Initial Validation. }\end{array}$ & $\begin{array}{l}\text { Slovakia/ } \\
\text { Slovakia }\end{array}$ & $\begin{array}{c}\text { Halama } \\
\text { dkk. }(2020)\end{array}$ & $\begin{array}{l}\text { 1. Validitas struktur dimensi }(55 / 93 \% \\
\text { butir BFI-2 memiliki nilai loading PCA }> \\
\text {.30). } \\
\text { 2. Validitas konvergen }(r>.5 \text { dengan } \\
\text { NEO-FFI dan TIPI). } \\
\text { 3. Reliabilitas konsistensi internal (rata- } \\
\text { rata Cronbach's Alpha }=.81) \text {. }\end{array}$ \\
\hline 6 & $\begin{array}{l}\text { Measurement invarance and } \\
\text { sex and age Differences of the } \\
\text { Big Five Inventory-2: } \\
\text { Evidence Fromthe Russian } \\
\text { Version. }\end{array}$ & $\begin{array}{l}\text { Rusia/ } \\
\text { Rusia }\end{array}$ & $\begin{array}{l}\text { Shchebetenko } \\
\text { dkk. (2020) }\end{array}$ & $\begin{array}{l}\text { 1. Validitas struktur dimensi }(59 / 98 \% \\
\text { butir BFI-2 memiliki nilai loading PCA }> \\
\text {.30). } \\
\text { 2. Validitas konvergen }(r>.5 \text { dengan } \\
\text { IPIP). } \\
\text { 3. Reliabilitas test-retest (rata-rata } \\
\text { Cronbach's Alpha }=.81 ; \text { retest }=.76) \text {. }\end{array}$ \\
\hline
\end{tabular}




\section{METODE}

\section{Partisipan}

Partisipan adalah 853 mahasiswa dari Perguruan Tinggi Negeri (PTN; $n=464)$ dan Swasta (PTS; $n=389$ ) di Jawa Timur dan Sumatera Utara. Partisipan dipilih dengan teknik non-random sampling. Kriteria inklusi yang ditentukan adalah mahasiswa aktif. Sementara itu, kriteria ekslusinya adalah apabila terdapat partisipan yang menjawab lebih dari satu kali, maka yang digunakan hanya jawaban pertama. Partisipan memiliki rentang usia 18-22 tahun $(M=20.08)$.

\section{Desain}

Penelitian ini menggunakan desain kuantitatif dan cross-sectional (Neuman \& Neuman 2014). Fokus utama dalam penelitian ini adalah pengujian validitas internal alat ukuryang mereplikasi dari penelitian sebelumnya (Soto \& John, 2017).

\section{Prosedur}

Pengambilan data dilakukan sebanyak tiga tahap secara daring dan tiap tahap mendapatkan jumlah partisipan yang berbeda. Pengambilan data secara bertahap dimaksudkan sebagai upaya untuk mendapatkan data yang bervariasi, sehingga dapat menjadi pelaporan uji validitas secara lengkap pada beberapa jenis sampel dalam penelitian ini, yakni kelompok mahasiswa Perguruan Tinggi Negeri (PTN) dan mahasiswa Perguruan Tinggi Swasta (PTS). Pada penelitian sebelumnya (Soto \& John, 2017), pelaporan hasil analisis juga dibandingan antara kelompok mahasiswa dan sampel internet, yaitu pengunjung website personalitylab.org yang berpartisipasi mengisi skala.

\section{Instrumen}

Terdapat dua alat ukur yang digunakan dalam penelitian ini, yakni Big Five Inventory-2 (BFI2) dan Big Five Inventory-1 (BFI-1). Kedua alat ukur tersebut memiliki skema teoretis yang sama, sehingga dapat digunakan untuk uji validitas konvergen.

Big Five Inventory-2 (BFI-2)

Alat ukur ini merupakan hasil penerjemahan. Secara konseptual, BFI-2 terbagi menjadi lima bagian dan setiap dimensinya memiliki tiga faset (sub-dimensi). Dimensi pertama, yaitu keterbukaan pemikiran (open-mindedness) memiliki faset ketertarikan pada seni dan keindahan (aesthetic 
sensitivity), keingintahuan intelektual (intellectual curiosity), dan imajinasi kreatif (creative imagination). Dimensi kedua, yaitu kehati-hatian (conscientiousness) memiliki faset keteraturan (organization), produktivitas (productiveness), dan tanggung jawab (responsibility). Dimensi ketiga, yaitu kesukaan terhadap hal di luar diri (extraversion) memiliki faset keramahan (sociability), ketegasan (assertiveness), dan semangat (energy level). Dimensi keempat, yaitu kesetujuan (agreeableness) memiliki faset belas kasihan (compassion), penghormatan (respectfulness), dan kemudahpercayaan (trust). Dimensi terakhir, yaitu kenegatifan emosi (negative emotionality) memiliki faset kecemasan (anxiety), depresi (depression), dan kelabilan emosi (emotional volatility). Pada setiap dimensi BFI-2, bentuk respons yang tersedia berupa skala Likert lima poin dari rentang angka 1-5 (1 = "Sangat Tidak Sesuai"; 5 = "Sangat Sesuai"). Spesifikasi alat ukur BFI-2 dapat dilihat pada Lampiran 1.

Big Five Inventory-1 (BFI-1)

Alat ukur BFI-1 yang digunakan dalam penelitian ini adalah alat ukur BFI versi terjemahan Bahasa Indonesia. Terdapat lima dimensi pada alat ukur ini, yaitu keterbukaan (openness), consicentiousness, ekstraversi (extraversion), kesetujuan (agreeableness), dan neurotisisme (neuroticism). BFI-1 menggunakan skala Likert lima poin dari angka 1-5 (1 = "Sangat Tidak Sesuai"; $5=$ "Sangat Sesuai”). Spesifikasi butir pada alat ukur BFI-1 dapat dilihat pada Lampiran 2.

\section{Teknik Analisis}

Prosedur analisis penelitian ini mereplikasi penelitian sebelumnya, ketika pada penelitian sebelumnya dilakukan analisis faktor pada level butir dan faset BFI-2 dengan menggunakan metode PCA dan metode rotasi faktor varimax. Analisis level butir dan faset dimaksudkan untuk melihat nilai loading factor setiap butir dan faset BFI-2 terhadap masing-masing dimensinya. Untuk meminimalisir bias kesetujuan pada alat ukur, maka pengujian analisis faktor menggunakan data terpusat (centering).

Prosedur data terpusat juga disarankan oleh penelitian BFI-2 sebelumnya (John dkk., 2008; Soto \& John, 2017). Mengikuti penelitian sebelumnya, metode data terpusat yang digunakan adalah sebagai berikut: 1). melihat nilai rata-rata pada masing-masing skor mentah (raw score) yang merupakan skor asli tanpa membalik skor unfavourable (Shchebetenko dkk., 2020; Soto \& John, 2017); dan 2). data kemudian dikurangi dengan nilai rata-rata tiap partisipan untuk memunculkan data terpusat. Secara konseptual, data yang dikurangi dengan nilai rata-rata akan mendapatkan data 
terpusat, sehingga dapat mereduksi jawaban dengan bias kesetujuan. Hasil data terpusat pada penelitian ini bergerak dari angka -3 hingga 3, ketika penggunaan data mentah memunculkan hasil analisis faktor yang mungkin akan memiliki arah negatif pada butir-butir unfavourable.

Penelitian ini juga melakukan analisis lanjutan terkait pengujian model pengukuran BFI-2, melalui analisis CFA. CFA merupakan metode analisis yang digunakan untuk menguji seberapa baik kesesuaian model struktur konstruk dari alat ukur dengan model teoretis yang digunakan (Hair dkk., 2010). Penelitian ini menggunakan CFA untuk menguji apakah model pengukuran pada BFI-2 hasil terjemahan sesuai dengan model struktur BFI-2 asli. Kriteria fit menggunakan indeks Root Mean Square Error of Approximation (RMSEA) dengan ketentuan $\leq .08$ sebagai acuan model memiliki kriteria good fit (Hair dkk., 2010). Indeks lainnya sebagai pertimbangan menggunakan CFI (Comparative Fit Index) dan TLI (Tucker Lewis Index), dengan nilai CFI dan TLI yang diharapkan adalah lebih besar dari .90 sebagai acuan model memiliki kriteria close fit (Hair dkk., 2010).

Terdapat setidaknya lima model struktur pengukuran yang direplikasi dari Soto dan John (2017) untuk diujikan, yakni: 1). Model pengujian tiap dimensi secara langsung; 2). Model pengujian setiap dimensi dengan variabel laten kesetujuan (latent acquiescence); 3). Model tiga faset; 4) model bifactor (tiga faset dan sekaligus pemisahan butir positf-negatif); serta 5). Model tiga faset dengan variabel laten kesetujuan. Ilustrasi tiap model dapat dilihat pada Figur 1.

Uji validitas kedua dalam penelitian ini melalui validitas konvergen, ketika pengujian dilakukan menggunakan analisis korelasi dengan BFI-1. Analisis korelasi dilakukan pada masingmasing dimensi BFI-2 dengan masing-masing dimensi BFI-1 untuk melihat sejauh mana kongruensi antar kedua alat ukur pada masing-masing dimensinya. 


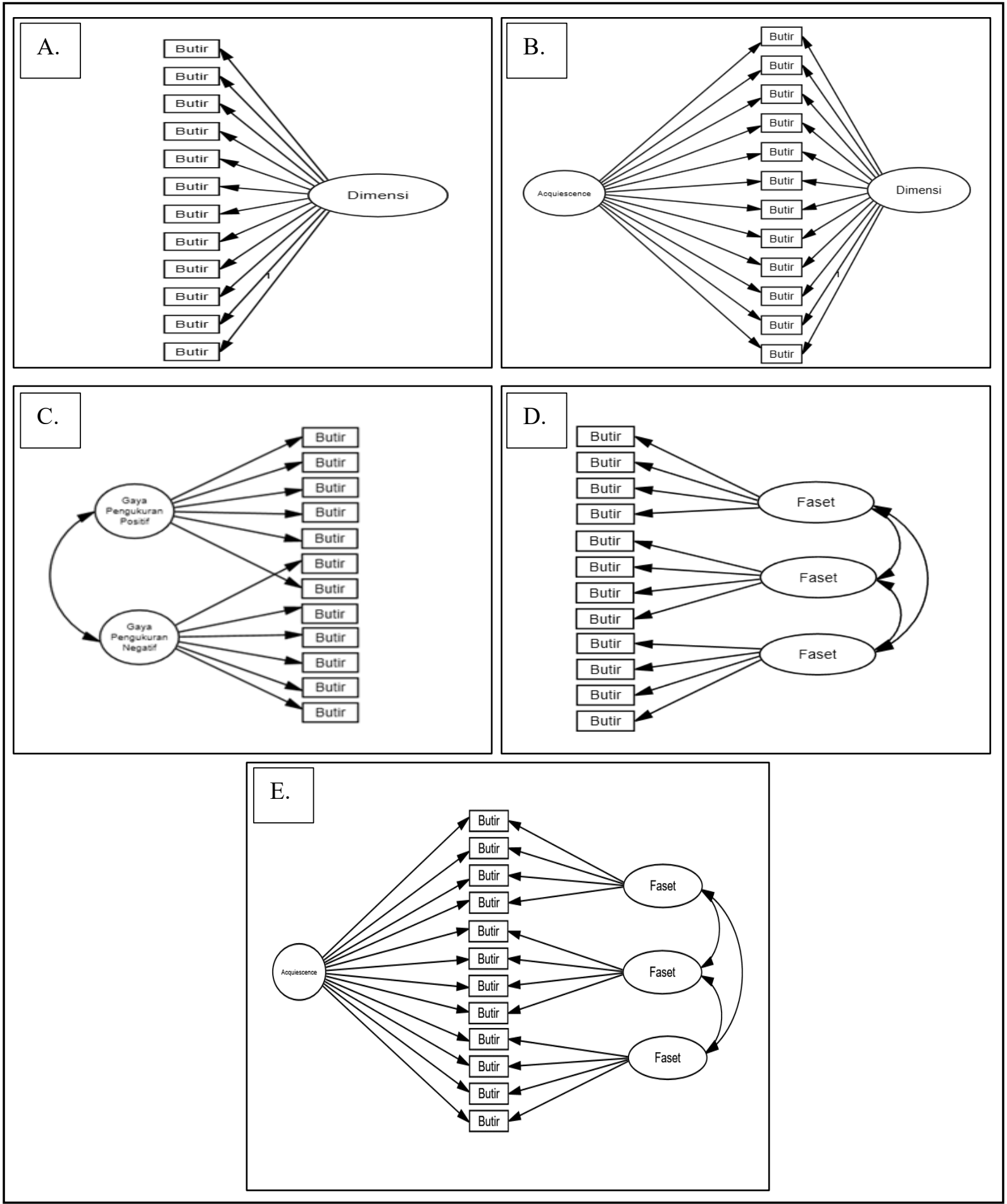

Figur 1. Ilustrasi Model Pengukuran: A). Dimensi Tunggal, B). Dimensi Tunggal dan Kesetujuan, C). Butir Positif dan Negatif, D). Tiga Faset, dan E). Tiga Faset dan Kesetujuan 


\section{HASIL}

\section{Validitas Struktur Internal}

Tabel 2 memuat informasi mengenai loading factor PCA butir terhadap tiap dimensi BFI-2. Hasil analisis PCA menunjukkan bahwa tidak semua butir memiliki nilai loading factor di atas .4 terhadap masing-masing dimensinya. Secara keseluruhan, untuk sampel gabungan, terdapat 50 (83\%) butir yang memiliki loading factor $>.40$ pada faset asli. Butir-butir dengan loading factor yang cenderung kecil $(<.40)$ pada dimensi kesukaan terhadap hal di luar diri, antara lain butir e6 (.37), e11r (-.34), e21 (.39), e51r (-.31). Pada dimensi kenegatifan emosi, hanya terdapat satu butir yang memiliki loading factor kecil, yakni butir n24 (.36). Sementara itu, pada dimensi kesetujuan terdapat beberapa butir yang memiliki loading factor yang juga kecil $(<.40)$, antara lain a17r $(-.19)$, a22r (.25), a37r (-.38) a42r (-.33) dan a47r (-.39). Uniknya, semua butir pada dimensi kesetujuan yang memiliki loading factor kecil merupakan butir unfavourable. Selain itu, butir a22 dan a42 memiliki cross-loading dengan dimensi lainnya, butir a22 bergeser ke dimensi kesukaan terhadap hal di luar diri dengan loading factor sebesar .48 .

Butir a22 ("Memulai adu pendapat dengan orang lain") merupakan butir negatif dari faset penghormatan. Butir ini kemungkinan dimaknai lebih kepada bentuk-bentuk sifat kesukaan terhadap hal di luar diri, terutama pada faset ketegasan. Butir a42 ("Mencurigai adanya niat buruk di balik perilaku orang lain") bergeser ke dimensi kenegatifan emosi. Butir a42 merupakan butir unfavourable pada faset kemudahpercayaan, butir ini kemungkinan dimaknai sebagai lawan dari sifat-sifat pada dimensi kenegatifan emosi. Hal ini dapat dilihat dari nilai cross loading yang bergeser ke dimensi kenegatifan emosi yang juga sama-sama bernilai negatif (-.43). Selain itu, terdapat juga butir lain yang memiliki cross loading dengan dimensi yang kurang tepat. Butir ini adalah butir dari faset semangat pada dimensi kesukaan terhadap hal di luar diri, yakni butir e56 ("Bersemangat tinggi") yang bergeser pada dimensi kehati-hatian dengan nilai loading sebesar .40. Pergeseran tersebut kemungkinan terjadi karena butir e56 memiliki pemaknaan yang mirip dengan dimensi kehati-hatian, lebih tepatnya dengan faset produktivitas. Salah satu indikator dari faset produktivitas adalah etos kerja, dan penggunaan kata bersemangat pada butir e56 kemungkinan dimaknai sama (seimbang) dengan indikator faset produktivitas (produktif, tekun, memiliki semangat, dan etos kerja). 
Tabel 2.

Loading Factor PCA Butir BFI-2 Bahasa Indonesia

$\frac{\text { Loading Factor PCA }}{\text { Kesuan }}$

terhadap hal di
luar diri $\quad$ Kesetujuan $\quad$ Kehati-hatian $\quad \begin{gathered}\text { Kenegatifan } \\ \text { emosi }\end{gathered} \begin{gathered}\text { Keterbukaan } \\ \text { pemikiran }\end{gathered}$

PTS PTN Gab. PTS PTN Gab. PTS PTN Gab. PTS PTN Gab. PTS PTN Gab. Kesukaan terhadap hal di luar diri

\begin{tabular}{|c|c|c|c|c|c|c|c|c|c|c|c|c|c|c|c|}
\hline \multicolumn{16}{|c|}{ Ketegasan } \\
\hline e ass $21^{*}$ & .55 & .21 & .39 & -.15 & -.33 & -.25 & .07 & .32 & .23 & -.04 & .08 & .01 & .07 & .07 & \\
\hline $\mathrm{e}$ ass $36 \mathrm{r}$ & -.52 & -.41 & -.47 & -.05 & .04 & -.03 & -.13 & -.27 & -.20 & -.09 & .00 & -.04 & -.13 & -.31 & -.23 \\
\hline $\mathrm{e}^{-}$ass_51 ${ }^{-} \mathrm{r}^{*}$ & 52 & .10 & -.31 & .07 & .19 & .16 & -.12 & -.32 & -.25 & -.10 & .08 & -.03 & -.24 & -.13 & -.21 \\
\hline ass_6 $6^{*}$ & 40 & .27 & .37 & -.08 & -.11 & -.08 & .31 & .18 & .24 & .24 & .12 & .18 & .06 & .26 & .17 \\
\hline \multicolumn{16}{|c|}{ Semangat } \\
\hline ene $11 r^{*}$ & -.34 & -.35 & -.36 & -.15 & -.03 & -.12 & -.34 & -.24 & -.27 & -.22 & .09 & -.15 & -.09 & -.14 & -.1 \\
\hline ene $26 r$ & -.44 & -.38 & -.41 & -.15 & -.04 & -.12 & & -.36 & -.36 & -.13 & .11 & -.11 & -.07 & -.07 & -.06 \\
\hline ene 41 & .62 & .45 & .55 & .12 & .04 & .10 & .3 & .38 & .36 & .29 & .28 & .28 & .03 & .10 & .06 \\
\hline ene $56^{*}$ & .49 & .42 & .47 & .13 & -.04 & .06 & .38 & .43 & .40 & .35 & .26 & .28 & .08 & .17 & \\
\hline \multicolumn{16}{|c|}{ Keramahan } \\
\hline soc 1 & .49 & .69 & .57 & .32 & .19 & .31 & .11 & .12 & .09 & .23 & .13 & .19 & .04 & -.02 & \\
\hline soc_16r & 69 & -.70 & -.68 & -.20 & -.08 & -.19 & & .06 & .01 & -.18 & .12 & -.15 & -.04 & -.08 & -.0 \\
\hline soc $31 \mathrm{r}$ & .66 & -.64 & -.66 & -.07 & .03 & -.06 & & -.02 & -.03 & -.33 & .20 & -.28 & -.03 & -.02 & -.04 \\
\hline soc 46 & 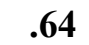 & .69 & .67 & .22 & .07 & .20 & -.03 & -.02 & -.05 & .16 & .04 & .10 & .01 & .10 & .01 \\
\hline \multicolumn{16}{|c|}{ Kesetujuan } \\
\hline \multicolumn{16}{|c|}{ Belas kasihan } \\
\hline com $17 \mathrm{r}^{*}$ & -.12 & -.12 & -.11 & -.19 & -.16 & -.16 & -.02 & -.03 & -.04 & .01 & .25 & .11 & -.15 & -.28 & -.2 \\
\hline $\operatorname{com}^{-2}$ & .09 & .30 & .18 & .66 & .40 & .55 & & .25 & .21 & -.03 & -.14 & -.06 & .09 & .08 & \\
\hline $\mathrm{a}^{-} \operatorname{com}^{-} 32$ & .10 & .31 & .20 & .68 & .46 & .60 &. & .11 & .09 & .06 & -.06 & -.01 & .03 & .20 & \\
\hline a_com_47 ${ }^{*}$ & -.24 & -.34 & -.28 & -.45 & -.25 & -.39 & -.18 & -.18 & -.16 & .09 & .07 & .10 & .03 & -.05 & \\
\hline \multicolumn{16}{|c|}{ Penghormatan } \\
\hline a_res_22r ${ }^{*}$ & .48 & .21 & .39 & -.25 & -.42 & -.34 & .05 & -.05 & -.01 & .22 & .12 & .14 & -.01 & .01 & \\
\hline a_res_37 $3 \mathrm{r}^{*}$ & .11 & .03 & .09 & -.41 & -.38 & -.38 & -.36 & -.30 & -.33 & -.14 & -.14 & -.17 & -.10 & -.03 & -.0 \\
\hline res 52 & .05 & .21 & .10 & .65 & .45 & .56 & .1 & .28 & .24 & .02 & .03 & .03 & .13 & .27 & .1 \\
\hline res_7 & -.02 & .16 & .02 & .57 & .52 & .56 & .18 & .26 & .22 & -.06 & .04 & .01 & .24 & .22 & \\
\hline \multicolumn{16}{|c|}{ Kemudahpercayaan } \\
\hline tru $12 \mathrm{r}$ & .05 & .04 & .07 & -.59 & -.50 & -.53 & 12 & -.23 & -.18 & -.10 & -.24 & -.19 & -.10 & -.06 & -.06 \\
\hline 27 & .01 & .18 & .06 & .54 & .56 & .55 & & -.05 & -.04 & .31 & .20 & .27 & .06 & -.06 & -.0 \\
\hline tru_ $42 r^{*}$ & -.01 & -.12 & -.06 & -.33 & -.28 & -.29 & .0 & -.10 & -.05 & -.43 & -.17 & -.33 & -.11 & .09 & -.0 \\
\hline tru 57 & 02 & .07 & .02 & .45 & .45 & .43 & .15 & .09 & .13 & .30 & .12 & .26 & .02 & .0( & -.0 \\
\hline \multicolumn{16}{|c|}{ Kehati-hatian } \\
\hline \multicolumn{16}{|c|}{ Keteraturan } \\
\hline org_18 & .04 & -.04 & -.07 & .12 & .20 & 15 & 7 & .66 & .69 & .15 & .04 & .07 & .05 & -.08 & \\
\hline c_org_33 & .04 & -.01 & .01 & .12 & .15 & .13 & & .62 & .68 & .09 & .06 & .08 & -.01 & -.03 & -.0 \\
\hline c_org_3r & -.06 & .03 & -.01 & -.17 & -.11 & -.14 & -.58 & -.57 & -.57 & -.06 & -.07 & -.08 & -.10 & .06 & -.0 \\
\hline c_org_48r & .02 & -.03 & .07 & -.32 & -.31 & -.34 & -.63 & -.55 & -.58 & .13 & -.01 & .07 & .01 & -.09 &.- \\
\hline \multicolumn{16}{|c|}{ Produktivitas } \\
\hline pro_23r & -.23 & -.07 & -.14 & -.06 & -.15 & -.09 & -.46 & -.55 & -.52 & -.18 & -.05 & -.14 & -.21 & -.08 & - . \\
\hline pro_38 & .18 & .08 & .12 & .15 & .09 & .11 & .43 & .49 & .46 & .27 & .23 & .26 & .23 & .09 & \\
\hline pro_53 & .21 & .13 & .16 & -.02 & .06 & .03 & .54 & .57 & .55 & .18 & .12 & .17 & .26 & .18 & .2 \\
\hline c_pro_8r & -.18 & -.09 & -.15 & -.12 & -.04 & -.09 & -.66 & -.58 & -.62 & -.07 & -.08 & -.07 & -.12 & -.15 & -.1 \\
\hline \multicolumn{16}{|c|}{ Tanggung jawab } \\
\hline c_resp_13 & .27 & .11 & .19 & .15 & .04 & .09 & .51 & .62 & .58 & .19 & .15 & .17 & .17 & .17 & .1 \\
\hline c_resp_28r & -.29 & -.05 & -.18 & .05 & .10 & .10 & -.44 & -.37 & -.42 & -.33 & -.29 & -.33 & -.05 & .07 & \\
\hline
\end{tabular}




\begin{tabular}{|c|c|c|c|c|c|c|c|c|c|c|c|c|c|c|c|}
\hline c_resp_43 & .35 & .16 & .26 & .25 & .08 & .16 & .36 & .45 & .43 & .14 & .19 & .16 & .16 & .34 & \\
\hline c resp 58r & -.08 & -.18 & -.14 & -.07 & -.05 & -.07 & -.53 & -.50 & -.51 & -.12 & .03 & -.03 & -.03 & 01 & \\
\hline \multicolumn{16}{|c|}{ Kenegatifan Emosi } \\
\hline \multicolumn{16}{|c|}{ Kecemasan } \\
\hline anx_19 & -.32 & -.29 & -.35 & -.06 & .11 & .01 & -.01 & -.09 & -.04 & -.61 & -.59 & -.57 & .05 & -.17 &.- \\
\hline anx & -.27 & -.19 & -.26 & .08 & .08 & .08 & -.08 & -.03 & -.05 & -.74 & -.64 & -.69 & -.02 & -.02 & \\
\hline anx_49r & .26 & .19 & .25 & -.15 & -.18 & -.18 & .02 & -.05 & -.01 & .70 & .64 & .67 & .01 & -.12 &.$-($ r \\
\hline anx_4r & .20 & .16 & .18 & .05 & .09 & .05 & .23 & .18 & .20 & .66 & .60 & .63 & .23 & .14 & \\
\hline \multicolumn{16}{|c|}{ Depresi } \\
\hline dep_24r ${ }^{*}$ & -.06 & -.05 & -.06 & .12 & .11 & .11 & .23 & .17 & .20 & .40 & .29 & .36 & .09 & -.04 & \\
\hline dep_39 & -.17 & -.22 & -.18 & -.01 & -.05 & -.03 & -.19 & -.03 & -.10 & -.70 & -.66 & -.69 & -.10 & .06 &.-( \\
\hline dep_54 & -.12 & -.15 & -.14 & -.04 & -.03 & -.03 & -.13 & -.06 & -.09 & -.68 & -.71 & -.70 & -.04 & .08 & \\
\hline dep_9r & .27 & .29 & .28 & .07 & .10 & .10 & .21 & .17 & .18 & .43 & .41 & .42 & .22 & .22 & \\
\hline \multicolumn{16}{|c|}{ Kelabilan Emosi } \\
\hline 14 & -.20 & .04 & -.07 & .06 & -.10 & .02 & -.17 & -.05 & -.12 & -.65 & -.63 & -.67 & -.10 & .01 & -.0 \\
\hline _emo_29r & .18 & -.04 & .06 & .13 & .21 & .13 & .15 & .07 & .13 & .63 & .60 & .65 & .13 & -.01 & \\
\hline _emo_44r & .01 & -.07 & -.03 & .25 & .19 & .19 & .26 & .20 & .24 & .50 & .55 & .53 & .13 & .12 & .1 \\
\hline emo_59 & -.07 & .02 & -.01 & -.27 & -.39 & -.30 & .02 & -.01 & -.01 & -.53 & -.45 & -.51 & -.05 & -.20 &.- \\
\hline \multicolumn{16}{|c|}{ Keterbukaan pemikiran } \\
\hline \multicolumn{16}{|c|}{ Ketertarikan pada seni dan keindahan } \\
\hline 20 & -.07 & -.01 & -.07 & .12 & .29 & .22 & -.03 & -.11 & -.09 & .09 & -.01 & .07 & .67 & .59 & \\
\hline 35 & -.03 & .03 & -.01 & .22 & .32 & .29 & .03 & -.04 & -.02 & .07 & .01 & .06 & .59 & .65 & \\
\hline $50 \mathrm{r}$ & .03 & -.03 & .04 & -.24 & -.23 & -.25 & -.05 & .07 & .01 & .10 & .04 & .04 & -.54 & -.45 &.- \\
\hline $5 r$ & .09 & -.06 & .04 & -.28 & -.28 & -.31 & .00 & .09 & .06 & .10 & .15 & .10 & -.58 & -.51 & 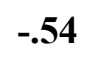 \\
\hline \multicolumn{16}{|c|}{ Imajinasi kreatif } \\
\hline . & .29 & .31 & .32 & -.06 & -.17 & -.09 & .22 & .30 & .26 & .32 & .07 & .18 & .51 & .40 & \\
\hline & -.20 & -.16 & -.21 & -.15 & .07 & -.05 & -.20 & -.33 & -.27 & -.16 & -.10 & -.11 & -.48 & -.55 & -.5 \\
\hline & -.26 & -.18 & -.23 & .06 & .04 & .01 & -.06 & -.22 & -.14 & -.12 & .06 & -.03 & -.51 & -.49 & -.5 \\
\hline cre_60 & .27 & .11 & .23 & -.03 & -.10 & -.07 & .20 & .23 & .23 & .35 & .15 & .26 & .55 & .51 & \\
\hline \multicolumn{16}{|c|}{ Keingintahuan intelektual } \\
\hline & .13 & .13 & .12 & .12 & .18 & .17 & .22 & .13 & .17 & .08 & .06 & .09 & .58 & .61 & \\
\hline & -.02 & -.02 & -.03 & .05 & .11 & .07 & -.08 & -.09 & -.09 & -.11 & -.05 & -.07 & -.53 & -.52 &.- .5 \\
\hline 40 & .15 & -.02 & .08 & -.02 & -.28 & -.15 & .29 & .29 & .30 & .11 & .13 & .13 & .55 & .54 & 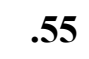 \\
\hline o_int_55r & -.10 & .01 & -.03 & -.01 & .15 & .06 & .01 & -.08 & -.01 & -.03 & .05 & -.06 & -.59 & -.44 & -.5 \\
\hline
\end{tabular}

Analisis pada sampel terpisah (PTS dan PTN) mendapatkan nilai loading factor yang cukup berbeda. Pada sampel PTS, setidaknya terdapat lima butir BFI-2 Indonesia yang memiliki loading factor lebih kecil dari .40. Sementara itu, pada sampel PTN terdapat 11 butir yang memiliki loading factor lebih kecil dari 40. Data pada sampel PTN memiliki pola yang hampir sama dengan sampel gabungan. Hal ini kemungkinan berkaitan dengan proporsi sampel PTN $(N=457)$ yang lebih besar dibandingkan sampel PTS $(N=351)$ terhadap data keseluruhan.

Pengujian selanjutnya adalah struktur internal tingkat faset alat ukur BFI-2 Indonesia, pengujian ini bertujuan untuk melihat struktur internal pada tiap faset pada BFI-2 Indonesia. Tabel 3 memberikan informasi mengenai hasil analisis PCA faset BFI-2 Indonesia dengan tingkat dimensi. 
Dari hasil analisis PCA diketahui bahwa masing-masing faset memiliki loading factor dengan nilai lebih besar dari .40 terhadap dimensinya. Pada dimensi kesukaan terhadap hal di luar diri, faset keramahan memiliki loading factor sebesar .79, faset ketegasan sebesar .64, dan faset semangat sebesar .57. Pada dimensi kesetujuan, faset belas kasihan memiliki loading factor sebesar .70, faset penghormatan sebesar .74, dan faset kemudahpercayaan sebesar .70. Pada dimensi kehati-hatian, faset keteraturan memiliki loading factor sebesar .77, faset produktivitas sebesar .74, dan faset tanggung jawab sebesar .67. Pada dimensi kenegatifan emosi, faset kecemasan memiliki loading factor sebesar .80, faset depresi sebesar .81, dan faset kelabilan emosi sebesar .81. Pada dimensi keterbukaan pemikiran, faset ketertarikan terhadap seni dan keindahan memiliki loading factor sebesar .74, faset keingintahuan intelektual sebesar .82, dan faset imajinasi kreatif sebesar .64.

Tabel 3.

Loading Factor PCA Faset BFI-2 Bahasa Indonesia

\begin{tabular}{|c|c|c|c|}
\hline $\begin{array}{l}\text { Kesukaan } \\
\text { terhadap hal } \\
\text { di luar diri }\end{array}$ & Kesetujuan & Kehati-hatian & $\begin{array}{c}\text { Kenegatifan } \\
\text { emosi }\end{array}$ \\
\hline
\end{tabular}

Gab. PTS PTN Gab. PTS PTN Gab. PTS PTN Gab. PTS PTN Gab. PTS PTN

\begin{tabular}{|c|c|c|c|c|c|c|c|c|c|c|c|c|c|c|c|}
\hline \multicolumn{16}{|c|}{ Kesukaan terhadap hal di luar diri } \\
\hline Keramahan & .79 & .72 & .84 & .16 & .15 & .10 & .03 & .13 & .01 & -.30 & -.35 & -.24 & .04 & .03 & .05 \\
\hline Ketę & .64 & .77 & .43 & -.18 & -.07 & -.22 & .33 & .18 & .44 & -.10 & -.15 & -.04 & .24 & .16 & .36 \\
\hline Sem & .57 & .56 & .56 & .11 & .11 & .08 & .47 & .48 & .47 & -.29 & -.36 & -.26 & .10 & .08 & .14 \\
\hline \multicolumn{16}{|c|}{ Kesetujuan } \\
\hline Belas & .43 & .32 & .48 & .70 & .82 & .56 & .11 & .13 & .12 & .15 & .08 & .22 & .14 & .08 & .22 \\
\hline Pengh & -.19 & -.32 & -.04 & .74 & .68 & .74 & .30 & .35 & .29 & -.02 & .03 & -.04 & .13 & .17 & 11 \\
\hline emuda & .05 & .03 & .10 & .70 & .74 & .69 & .09 & .05 & .11 & -.42 & -.42 & -.34 & .01 & .12 & -.1 \\
\hline \multicolumn{16}{|c|}{ Kehati-hatian } \\
\hline $\mathrm{K}$ & .02 & .05 & -.02 & 23 & .19 & .24 & .77 & .81 & & -.04 & -.07 & -.02 & .03 & .06 & \\
\hline Prod & .20 & .26 & .13 & .13 & .06 & .20 & .7 & .72 & .74 & -.20 & -.26 & -.13 & .21 & .26 & 1 \\
\hline Tanggu & .23 & .39 & .10 & .06 & .15 & .04 & .67 & .54 & .71 & -.26 & -.26 & -.23 & .09 & .14 & \\
\hline \multicolumn{16}{|c|}{ Kenegatifan emosi } \\
\hline Kece & -.31 & -.34 & -.25 & .08 & .02 & .11 & -.09 & -.05 & .10 & .80 & .81 & .80 & -.07 & -.06 & -.0 \\
\hline $\mathrm{De}$ & -.16 & -.15 & -.20 & -.05 & -.03 & -.06 & -.22 & -.24 & -.18 & .81 & .82 & .79 & -.06 & -.14 & .0 \\
\hline Celabila & -.04 & -.15 & .11 & -.18 & -.15 & -.29 & -.17 & -.18 & -.12 & .81 & .81 & .78 & -.11 & -.13 &.-( \\
\hline \multicolumn{16}{|c|}{ Keterbukaan pemikiran } \\
\hline $\begin{array}{l}\text { Ketertar } \\
\text { seni dan }\end{array}$ & -.02 & -.12 & .04 & .33 & .18 & .40 & -.07 & .10 & -.15 & .01 & -.01 & .03 & .74 & .77 & .6 \\
\hline $\begin{array}{l}\text { Keingintahuan } \\
\text { intelektual }\end{array}$ & .10 & .19 & .03 & -.04 & .04 & -.07 & .17 & .12 & .13 & -.10 & -.11 & -.07 & .82 & .82 & .8 \\
\hline Imajinasi kreatif & .33 & .37 & .25 & .01 & .08 & -.01 & .30 & .17 & .38 & -.19 & -.32 & -.07 & .64 & .65 & .6 \\
\hline
\end{tabular}

Pada sampel gabungan, terdapat tiga faset yang tergolong cross loading, yakni faset semangat, belas kasihan, dan kemudahpercayaan. Ketiga faset ini memiliki loading factor cukup tinggi terhadap dimensi aslinya, yaitu kesukaan terhadap hal di luar diri (.57) dan kesetujuan (.70), tetapi juga 
memiliki loading factor lebih besar dari .40 terhadap dimensi kehati-hatian (.47), kesukaan terhadap hal di luar diri (.43), dan kenegatifan emosi (-.42). Meskipun demikian, ketiga tersebut faset masih lebih tepat digolongkan mengukur dimensi awal (kesukaan terhadap hal di luar diri dan kesetujuan), mengingat masih lebih besarnya loading factor yang dimiliki pada dimensi-dimensi asli.

Secara keseluruhan, hasil pengukuran terhadap 15 faset BFI-2 Indonesia pada penelitian ini terbukti memiliki pengelompokan yang memadai dengan tiap dimensi sesuai dengan struktur teoretis BFI-2 versi asli. Selain itu, hasil PCA pada level faset juga menunjukkan bahwa semua faset kunci (utama) memiliki nilai loading factor tertinggi pada dimensi masing-masing. Misalnya, faset keramahan memiliki loading factor tertinggi pada dimensi kesukaan terhadap hal di luar diri (sebesar .79). Hal ini menegaskan bahwa butir-butir pada dimensi kesukaan terhadap hal di luar diri lebih banyak mengukur mengenai faset keramahan.

\section{Hasil Analisis CFA}

Penelitian ini juga menyertakan pengujian struktur BFI-2 pada level faset dan dimensi dengan menggunakan CFA. Pengujian CFA juga dilakukan oleh pengembang alat ukur BFI-2 (Soto \& John, 2017). Sebagai ketentuan kesesuian model fit, penelitian ini menggunakan Indeks RMSEA, TLI, dan CFI. Tabel 4 menampilkan hasil analisis CFA pada keempat model pengukuran. Berdasarkan hasil analisis CFA, diketahui bahwa nilai fit indices model satu dimensi memiliki nilai fit yang cenderung kecil $(M \mathrm{RMSEA}=.103 ; M \mathrm{TLI}=.683 ; M \mathrm{CFI}=.813)$ apabila dibandingkan dengan model tiga faset $(M$ RMSEA $=.062 ; M$ TLI $=785 ; M$ CFI $=.929)$ yang memiliki perbedaan yang cukup substansial.

Temuan ini membuktikan bahwa penggunan model pengukuran level dimensi (BFI-1) masih memerlukan evaluasi dengan model yang lebih kompleks, yaitu model level faset (sub-dimensi) yang digunakan pada BFI-2. Pada model bifactor level faset, kelima dimensi memiliki fit indices yang tinggi $(M$ RMSEA $=.040 ; M$ TLI $=.963 ; M$ CFI $=.978)$. Hasil ini mengkonfirmasi bahwa model pengukuran struktur BFI-2 di level faset dengan model bifactor dapat mereduksi bias kesetujuan. Model bifactor ini dipopulerkan oleh Billiet dan McClendon (2000), sebagaimana tujuan dan fungsinya, model bifactor digunakan untuk membantu peneliti kepribadian dalam mereduksi respons kesetujuan dan mendapatkan hasil pengukuran yang lebih jernih (Denissen dkk., 2020; Soto \& John, 2017). 
Tabel 4.

Indeks Fit pada Kelima Model Pengukuran

\begin{tabular}{|c|c|c|c|c|c|c|c|c|c|}
\hline \multirow{2}{*}{ Model } & \multicolumn{3}{|c|}{ CFI } & \multicolumn{3}{|c|}{ TLI } & \multicolumn{3}{|c|}{ RMSEA } \\
\hline & Gab. & PTS & PTN & Gab. & PTS & PTN & Gab. & PTS & PTN \\
\hline \multicolumn{10}{|c|}{ Kesukaan terhadap hal di luar diri } \\
\hline Dimensi Tunggal & .732 & .586 & .588 & .792 & .586 & .588 & .122 & .141 & .107 \\
\hline Dimensi Tunggal dan Acquiscence & .689 & .738 & .635 & .807 & .738 & .546 & .106 & .113 & .102 \\
\hline Butir Positif dan Negatif & .911 & .608 & .765 & .890 & .511 & .768 & .073 & .139 & .082 \\
\hline Tiga Faset & .724 & .828 & .570 & .344 & .828 & .475 & .102 & .127 & .110 \\
\hline Tiga Faset dan Acquiscence & .940 & .939 & .933 & .947 & .897 & .887 & .055 & .064 & .051 \\
\hline \multicolumn{10}{|c|}{ Kesetujuan } \\
\hline Dimensi Tunggal & .768 & .723 & .621 & .848 & .723 & .621 & .096 & .086 & .091 \\
\hline Dimensi Tunggal dan Acquiscence & .825 & .867 & .730 & .862 & .835 & .664 & .068 & .060 & .078 \\
\hline Butir Positif dan Negatif & .880 & .821 & .623 & .850 & .777 & .531 & .065 & .070 & .092 \\
\hline Tiga Faset & .839 & .933 & .690 & .775 & .933 & .599 & .082 & .070 & .085 \\
\hline Tiga Faset dan Acquiscence & .972 & .979 & .918 & .956 & .984 & .862 & .030 & .028 & .050 \\
\hline \multicolumn{10}{|c|}{ Kehati-hatian } \\
\hline Dimensi Tunggal & .677 & .431 & .522 & .749 & .431 & .522 & .147 & .159 & .127 \\
\hline Dimensi Tunggal dan Acquiscence & .640 & .507 & .503 & .674 & .398 & .393 & .117 & .148 & .129 \\
\hline Butir Positif dan Negatif & .866 & .434 & .628 & .834 & .296 & .537 & .095 & .160 & .113 \\
\hline Tiga Faset & .810 & .626 & .737 & .824 & .626 & .660 & .110 & .133 & .097 \\
\hline Tiga Faset dan Acquiscence & .955 & .959 & .916 & .973 & .931 & .861 & .048 & .050 & .062 \\
\hline \multicolumn{10}{|c|}{ Kenegatifan emosi } \\
\hline Dimensi Tunggal & .779 & .781 & .753 & .834 & .781 & .753 & .130 & .157 & .132 \\
\hline Dimensi Tunggal dan Acquiscence & .899 & .879 & .899 & .772 & .852 & .650 & .097 & .117 & .097 \\
\hline Butir Positif dan Negatif & .877 & .784 & .762 & .846 & .731 & .703 & .097 & .157 & .113 \\
\hline Tiga Faset & .834 & .802 & .812 & .744 & .802 & .757 & .116 & .153 & .119 \\
\hline Tiga Faset dan Acquiscence & .975 & .973 & .971 & .957 & .955 & .950 & .056 & .064 & .054 \\
\hline \multicolumn{10}{|c|}{ Keterbukaan pemikiran } \\
\hline Dimensi Tunggal & .645 & .445 & .476 & .639 & .445 & .476 & .143 & .151 & .125 \\
\hline Dimensi Tunggal dan Acquiscence & .736 & .654 & .714 & .644 & .569 & .682 & .096 & .120 & .142 \\
\hline Butir Positif dan Negatif & .864 & .726 & .695 & .831 & .658 & .621 & .090 & .107 & .096 \\
\hline Tiga Faset & .870 & .792 & .772 & .731 & .792 & .706 & .089 & .095 & .085 \\
\hline Tiga Faset dan Acquiscence & .952 & .976 & .911 & .984 & .959 & .849 & .048 & .037 & .061 \\
\hline
\end{tabular}

\section{Validitas Konvergen dengan Alat Ukur BFI-1}

Pengujian selanjutnya adalah validitas konvergen BFI-2 dengan alat ukur BFI-1. Tabel 5 memberikan informasi mengenai hasil analisis korelasi antar dimensi pada alat ukur BFI-2 dan BFI1. Hasil analisis menunjukkan bahwa keseluruhan dimensi pada alat ukur BFI-2 memiliki nilai korelasi dengan arah positif terhadap masing-masing dimensi pada alat ukur BFI-1. Dimensi Kesukaan terhadap hal di luar diri mendapatkan nilai $r$ sebesar .57, kesetujuan sebesar .50, kehatihatian sebesar .50, kenegatifan emosi sebesar .62, dan keterbukaan pemikiran sebesar .51 . 
Tabel 5.

Analisis Korelasi Dimensi BFI-1 dan BFI-2

\begin{tabular}{|c|c|c|c|c|c|c|c|c|c|c|c|c|c|}
\hline \multirow{2}{*}{ BFI-1 } & \multicolumn{3}{|c|}{$\begin{array}{l}\text { Kesukaan } \\
\text { terhadap hal } \\
\text { di luar diri }\end{array}$} & \multicolumn{3}{|c|}{ Kesetujuan } & \multicolumn{3}{|c|}{ Kehati-hatian } & \multicolumn{3}{|c|}{ Kenegatifan emosi } & \multirow{2}{*}{$\begin{array}{c}\begin{array}{c}\text { Keterbukaan } \\
\text { pemikiran }\end{array} \\
\text { Total PTS PTN }\end{array}$} \\
\hline & Total & PTS & PTN & Total & PTS & PTN & Total & PTS & PTN & Total & PTS & PTN & \\
\hline Ekstra & .57 & .86 & .53 & .21 & .27 & .27 & .32 & .41 & .42 & -.42 & -.46 & -.50 & $\begin{array}{lll}.21 & .24 & .21\end{array}$ \\
\hline Keteguhan Hati & .11 & .18 & .16 & .50 & .78 & .48 & .21 & .25 & .27 & -.12 & -.17 & -.18 & $\begin{array}{lll}.17 & .20 & .19\end{array}$ \\
\hline Conscientiousness & .27 & .33 & .35 & .22 & .31 & .32 & .50 & .85 & 46 & -.28 & -.32 & -.36 & $\begin{array}{lll}.25 & .19 & .18\end{array}$ \\
\hline Emosionalitas negatif & -.26 & -.40 & -.40 & -.24 & -.28 & -.29 & -.29 & -.35 & -.36 & .62 & .91 & .55 & $\begin{array}{lll}-.20 & -.17 & -.13\end{array}$ \\
\hline Berpikiran terbuka & 19 & .28 & .27 & .16 & .20 & .20 & .25 & .30 & .29 & -.25 & -.29 & -.30 & $\begin{array}{lll}.51 & .76 & .46\end{array}$ \\
\hline
\end{tabular}

Hasil ini menunjukkan bahwa kelima dimensi BFI-2 memiliki kongruensi dengan dimensidimensi pada BFI-1. Apabila dibandingkan dengan penelitian terdahulu, nilai korelasi yang didapatkan pada penelitian ini menunjukkan hasil yang relatif kecil $(\mathrm{Mr}=.54)$, perbandingan hasil uji korelasi dengan penelitian sebelumnya secara lebih lengkap dapat dilihat pada Tabel 6. Hasil pengujian pada sampel terpisah mendapatkan nilai yang berbeda. Pada sampel PTN, dimensi kesukaan terhadap hal di luar diri mendapatkan nilai $r$ sebesar .53 , kesetujuan sebesar .48 , kehatihatian sebesar .46, kenegatifan emosi sebesar .55, dan keterbukaan pemikiran sebesar .46. Sebagai pembanding, hasil pengujian korelasi antara BFI-2 dengan BFI-1 pada sampel PTS menunjukkan nilai korelasi yang lebih besar, ketika dimensi kesukaan terhadap hal di luar diri mendapatkan nilai $r$ sebesar .86, kesetujuan sebesar .78, kehati-hatian sebesar .85, kenegatifan emosi sebesar .91, dan keterbukaan pemikiran sebesar .76. Hasil ini menunjukkan bahwa kelima dimensi BFI-2 memiliki kongruensi yang lebih besar dengan dimensi-dimensi BFI-1 pada pengujian sampel PTS.

Tabel 6.

Perbandingan Nilai Korelasi dengan Penelitian Sebelumnya

\begin{tabular}{|c|c|c|c|c|c|c|}
\hline BFI-2 & $\begin{array}{l}\text { Penelitian } \\
\text { Saat ini } \\
\text { (BFI-1) }\end{array}$ & $\begin{array}{c}\text { Soto \& John } \\
\text { (2017) } \\
\text { (BFI-1) }\end{array}$ & $\begin{array}{c}\text { Rammstedt dkk. } \\
(2018) \\
(\text { NeoPiR) }\end{array}$ & $\begin{array}{c}\text { Denissen } \\
\text { dkk. (2020) } \\
\text { (IPIP) }\end{array}$ & $\begin{array}{c}\text { Halama dkk. } \\
(2020) \\
(\text { NeoFFI) }\end{array}$ & $\begin{array}{l}\text { Vedel dkk. } \\
(2021) \\
(\mathrm{MM})\end{array}$ \\
\hline $\begin{array}{l}\text { Kesukaan terhadap } \\
\text { hal di luar diri }\end{array}$ & .57 & .93 & .80 & .76 & .75 & .85 \\
\hline Kesetujuan & .50 & .93 & .78 & .61 & .72 & .75 \\
\hline Kehati-hatian & .50 & .91 & .81 & .73 & .77 & .89 \\
\hline Kenegatifan emosi & .62 & .94 & .87 & .81 & .73 & .72 \\
\hline $\begin{array}{l}\text { Keterbukaan } \\
\text { pemikiran }\end{array}$ & .51 & .87 & .66 & .62 & .63 & .81 \\
\hline
\end{tabular}




\section{Reliabilitas Dimensi BFI-2}

Penelitian ini juga menguji reliabilitas internal butir BFI-2 pada masing-masing dimensinya melalui analisis Cronbach's Alpha. Tabel 7 menunjukkan hasil analisis Cronbach's Alpha pada kelima dimensi BFI-2. Hasil analisis keseluruahn sampel (gabungan) menunjukkan bahwa empat dari lima dimensi BFI-2 memiliki nilai Cronbach's Alpha lebih besar dari .70, artinya masih terdapat satu dimensi yang memiliki nilai Cronbach's Alpha di bawah .70. Dimensi ini adalah dimensi kesetujuan dengan nilai Cronbach's Alpha sebesar .689. Hasil serupa juga terdapat di pengujian pada sampel PTN, ketika dimensi kesetujuan memiliki nilai Cronbach's Alpha sebesar .659. Terlepas dari itu, kelima dimensi pada sampel PTS memiliki Cronbach's Alpha lebih besar dari .70. Hal ini menunjukkan bahwa BFI-2 Indonesia telah memiliki nilai reliabilitas (konsistensi internal) yang memadai pada pengujian di sampel ini.

Tabel 7.

Cronbach's Alpha Dimensi

\begin{tabular}{lccc}
\hline \multirow{2}{*}{ Dimensi } & \multicolumn{3}{c}{ Nilai Cronbach's Alpha } \\
\cline { 2 - 4 } & Gabungan & Sampel PTS & Sampel PTN \\
\hline Kesukaan terhadap hal di luar diri & .807 & .837 & .770 \\
Kesetujuan & .689 & .715 & .659 \\
Kehati-hatian & .826 & .838 & .812 \\
Kenegatifan emosi & .852 & .870 & .820 \\
Keterbukaan pemikiran & .796 & .816 & .771 \\
\hline
\end{tabular}

\section{DISKUSI}

Hasil analisis struktur internal melalui PCA menunjukkan sebanyak 50 dari 60 butir (83\%) BFI-2 Indonesia memiliki loading factor $\geq .40$, artinya hanya tersisa 10 butir yang memiliki loading factor kecil $(<.40)$ terhadap dimensinya. Selain itu, ditemukan juga beberapa butir yang memiliki cross loading dengan dimensi lainnya, sehingga butir-butir tersebut walaupun dapat dipertahankan, tetapi perlu dipertimbangkan untuk direvisi kembali.

Hasil PCA penelitian ini mirip dengan penelitian Halama dkk. (2020) yang melaporkan bahwa tidak semua butir memiliki loading factor terhadap dimensinya, kemudian beberapa butir negatif juga memiliki cross loading dengan dimensi lainnya. Penelitian Shchebetenko dkk. (2020) juga melaporkan bahwa terdapat satu butir yang memiliki cross loading dengan dimensi lainnya. Hal 
serupa juga pernah ditemukan pada penelitian Ramdhani (2012) bahwa sebagian besar butir-butir unfavourable pada dimensi BFI-1 versi Indonesia memiliki muatan faktor yang kecil $(\lambda \leq .30)$.

Serupa dengan penelitian sebelumnya (Soto \& John, 2017), analisis PCA di level faset menunjukkan bahwa terdapat 15 faset yang memiliki loading factor yang sesuai dengan masingmasing dimensinya. Namun, terdapat satu faset yang memiliki nilai cross-loading sebesar .40 dengan dimensi lainnya. Hal serupa juga pernah dilaporkan pada penelitian Rammstedt dkk. (2018) bahwa faset belas Kasihan memiliki loading factor sebesar .47 terhadap dimensinya dan juga memiliki cross loading ESEM sebesar .30 dengan dimensi kesukaan terhadap hal di luar diri. Selain itu, masingmasing faset menunjukkan pengelompokan yang kuat dengan masing-masing dimensinya sesuai dengan struktur pengukuran yang terdapat pada BFI-2 versi asli.

Hasil analisis CFA penelitian ini mendukung penelitian terdahulu (Soto \& John, 2017) dan beberapa penelitian lainnya (misalnya, Denissen dkk., 2020; Halama dkk., 2020; Shchebetenko dkk., 2020; Vedel dkk., 2021) yang melaporkan bahwa struktur faset memiliki fit indices yang lebih baik dari dimensi (fit dimensi < fit faset). Artinya, level faset BFI-2 memiliki model pengukuran yang lebih baik dibandingkan model pengukuran dimensi. Sama seperti penelitian sebelumnya, pada penelitian ini juga ditemukan korelasi positif antara dimensi BFI-2 dengan dimensi BFI-1, tetapi tidak sebesar penelitian sebelumnya. Hasil analisis reliabilitas dimensi BFI-2 Indonesia berbeda dari penelitian sebelumnya (Soto \& John, 2017), ketika semua dimensi BFI-2 pada penelitian sebelumnya memiliki nilai Cronbach's Alpha lebih besar dari .70 pada kedua sampel (mahasiswa dan sampel internet). Sementara itu, pada penelitian ini dimensi Kesetujuan memiliki nilai reliabilitas yang cenderung kecil (<.685) pada sampel keseluruhan, serta pada sampel PTN yang hanya sebesar .659. Namun, pada sampel PTS kelima dimensi memiliki nilai Cronbach's Alpha lebih besar dari .70.

Sebagai pelaporan awal mengenai adaptasi alat ukur BFI-2 pada konteks Indonesia, implikasi utama penelitian adalah penyediaan BFI-2 dapat digunakan pada penelitian di Indonesia (menggunakan bahasa Indonesia). Dalam penelitian ini, sudah dilaporkan sejumlah informasi mendasar tentang properti psikometris alat ukur. Informasi tersebut dapat dijadikan bukti validitas hasil pengukuran, khususnya di bidang struktur internal dan hubungan dengan variabel lain. Penelitian lanjutan, khususnya pengumpulan sumber validitas lain (misalnya, berdasarkan penilaian panelis terhadap butir-butir BFI-2 atau evaluasi proses respons para responden) masih sangat diperlukan sebagai pelengkap dan penyempurna laporan validitas hasil pengukuran BFI-2 pada konteks Indonesia.

Penelitian ini juga memiliki keterbatasan, yaitu tidak menyertakan butir terjemahan alternatif pada proses pengambilan data. Butir alternatif berfungsi sebagai kandidat pengganti apabila terdapat 
butir yang harus direvisi (disisihkan). Metode ini dilakukan pada beberapa (tidak semua) penelitian adaptasi BFI-2 sebelumnya. Hal tersebut dilakukan dengan pertimbangan sudah banyaknya jumlah butir yang diberikan kepada partisipan. Kelemahan kedua berkaitan dengan kriteria sampel. Sampel penelitian kali ini hanya terbatas pada mahasiswa, tetapi sudah melibatkan mahasiswa PTN dan PTS. Pada penelitian selanjutnya disarankan melibatkan sampel yang lebih bervariatif, misalnya melibatkan para pekerja dari berbagai bidang pekerjaan.

Nilai Cronbach's Alpha yang cenderung kecil pada dimensi kesetujuan disebabkan karena butir dimaknai berbeda ataupun kualitas dari beberapa butir terjemahan yang kurang mewakili makna dari indikator kesetujuan. Terbukti pada hasil PCA, terdapat beberapa butir yang memiliki cross loading dengan dimensi yang tidak sesuai dan cenderung memiliki loading factor yang kecil $(<.4)$ dengan dimensi aslinya. Selain itu, bukti penelitian menunjukkan bahwa dimensi ini juga memiliki nilai reliabilitas internal yang cenderung lebih kecil. Schmitt dkk. (2007) melaporkan pengujian dimensionalitas BFI pada 56 negara (30 bahasa) dan hasil analisis penelitian tersebut menyatakan bahwa dimensi Kesetujuan memiliki nilai reliabilitas paling kecil jika dibandingkan dengan dimensi lainnya. Oleh karena itu, pada penelitian selanjutnya perlu dilakukan pengkajian ulang secara lebih mendalam. Evaluasi panelis secara kuantitatif terhadap isi butir-butir bermasalah dapat memberikan sumber bukti validitas berdasarkan isi. Sebagai pelengkap, evaluasi proses respons dari para partisipan juga dapat dilakukan untuk meningkatkan kualitas dan akurasi butir dengan definisi konseptual.

\section{SIMPULAN DAN SARAN}

\section{Simpulan}

BFI-2 versi Bahasa Indonesia belum terbukti memiliki validitas konstruk pada level dimensi, sebanyak lima dari enam butir juga tidak memiliki loading factor yang cukup terhadap dimensinya, sedangkan pengujian struktur internal di level faset menunjukkan bahwa 15 faset BFI-2 Indonesia memiliki loading factor yang baik dengan masing-masing dimensinya. Pengujian validitas berdasarkan sumber bukti struktur internal dan hubungan dengan variabel lain menunjukkan bahwa hasil pengukuran BFI-2 Indonesia tergolong valid untuk mengukur kepribadian menurut teori Big Five Personality pada sampel mahasiswa. Pengujian terhadap bias respons kesetujuan meningkatkan indeks kesesuaian pada model pengukuran, baik tingkat dimensi maupun faset alat ukur BFI-2 versi Bahasa Indonesia. Hal ini terbukti dari peningkatan indeks fit yang cukup substansial pada model 
bifactor di tingkat dimensi dan faset. Walaupun alat ini telah akurat dalam memetakan kepribadian dalam lima dimensi berbeda, hasil terbaik diperoleh ketika kepribadian dimaknai sebagai konstruk yang memiliki lima dimensi dengan tiga faset unik pada tiap dimensinya. Dengan demikian, BFI-2 Indonesia dapat digunakan untuk melakukan pengukuran kepribadian Big Five dengan 15 faset yang makin spesifik.

Masih adanya sejumlah butir yang memiliki loading factor lemah atau cross loading mencerminkan adanya ketidaksempurnaan hasil pengukuran BFI-2 Indonesia. Meskipun demikian, alat ukur ini tetap dapat digunakan, khususnya dalam konteks penelitian kepribadian pada tingkat kelompok atau masyarakat. Agar dapat digunakan secara makin akurat dan sempurna untuk melakukan diagnosis kepribadian pada tingkat individu, diperlukan revisi berdasarkan uji validitas lanjutan, khususnya berdasarkan sumber bukti berupa isi dan proses respons. Hal tersebut sangatlah penting guna meningkatkan keselarasan antara pemaknaan partisipan dan definisi konseptual.

\section{Saran Teoretis}

Hasil penelitian menunjukkan bahwa BFI-2 Indonesia memiliki properti psikometrik yang cukup baik, sehingga alat ukur ini dapat digunakan dalam konteks penelitian. Namun, beberapa butir hasil terjemahan memiliki nilai loading factor yang kurang baik terhadap dimensinya. Penelitian selanjutnya dapat mempertimbangkan untuk melakukan perbaikan pada butir-butir tersebut. Perbaikan butir ini dilakukan untuk pengujian alat ukur BFI-2 yang lebih baik, ketika dilakukan uji validitas alat ukur yang lebih lengkap lagi, misalnya validitas melalui sumber bukti isi (content), respons proses, maupun dampak atau konsekuensi dari pengukuran. Hal ini dapat melengkapi pelaporan properti psikometris alat ukur BFI-2 versi Indonesia, sehingga secara teoretis alat ukur BFI-2 versi Indonesia dapat dipergunakan secara baku dengan adanya bukti pelaporan properti psikometrik yang lengkap.

\section{Saran Praktis}

Meskipun belum sempurna, alat ukur BFI-2 versi Indonesia tetap valid dan reliabel mengukur kepribadian individu menurut teori Big Five Personality terbaru, yang mengusulkan adanya tiga faset spesifik pada tiap dimensi (Soto \& John, 2017). Dengan demikian, temuan penelitian ini makin memperkokoh dukungan terhadap model pengukuran BFI-2 yang sebelumnya telah divalidasi di Belanda (Denissen dkk. 2020), Cina (Zhang dkk., 2021), Denmark (Vedel dkk., 2021), Jerman (Rammstedt dkk., 2018), Rusia (Shchebetenko dkk., 2020), dan Slovakia (Halamadkk., 2020). Versi terjemahan yang dihasilkan juga melengkapi koleksi terjemahan yang 
telah mencapai setidaknya 40 bahasa dengan mayoritas didukung oleh International Situations Project (Soto, 2021a). BFI-2 versi Bahasa Indonesia telah dapat digunakan sebagai instrumen pada penelitian non-komersial berupa survei maupun intervensi yang berhubungan dengan kepribadian Big Five (Soto, 2021b). Penerapan komersial dari alat ukur ini perlu mendapatkan izin tertulis dari Oliver P. John selaku pengembang BFI-1 sekaligus direktur Berkeley Personality Laboratory dan Christopher J. Soto selaku pengembang BFI-2 sekaligus direktur Colby Personality Laboratory.

\section{UCAPAN TERIMA KASIH}

Ucapan terima kasih kepada mahasiswa dari beberapa perguruan tinggi yang berpartisipasi sebagai responden, juga kepada Fakultas Psikologi Universitas Surabaya, Fakultas Psikologi Universitas Sumatera Utara dan Fakultas Ilmu Sosial Budaya Universitas Gajayana Malang yang telah banyak memberikan layanan, fasilitas, dan dukungan dalam proses pengambilan data penelitian, serta semua pihak yang mungkin tidak disebutkan.

\section{ASPEK ETIK STUDI}

\section{Pernyataan Etik}

Seluruh prosedur yang dilakukan pada studi ini telah sesuai dengan Deklarasi Helsinki tahun 1964 dan segala adendumnya atau dengan standar etika yang relevan.

\section{Konflik Kepentingan}

Penulis menyatakan tidak memiliki konflik kepentingan.

\section{Ketersediaan Data}

Data yang digunakan dalam studi ini dapat diakses dengan menghubungi penulis melalui surel: std@staff.ubaya.ac.id

\section{REFERENSI}

Billiet, J. B., \& McClendon, M. J. (2000). Modeling acquiescence in measurement models for two balanced sets of items. Structural Equation Modeling, 7, 608-628. http://dx.doi.org/10.1207/S15328007SEM0704_5

Bleidorn, W., Klimstra, T. A., Denissen, J. J., Rentfrow, P. J., Potter, J., \& Gosling, S. D. (2013). Personality maturation around the world: A cross-cultural examination of social-investment theory. Psychological Science, 24(12), 2530-2540. https://doi.org/10.1177/0956797613498396

Denissen, J. J., Geenen, R., Soto, C. J., John, O. P., \& Van Aken, M. A. (2020). The Big Five Inventory-2: Replication of psychometric properties in a Dutch adaptation and first evidence 
for the discriminant predictive validity of the facet scales. Journal of Personality Assessment, 102(3), 309-324. https://doi.org/10.1080/00223891.2018.1539004

Hair, J. F., Anderson, R. E., Babin, B. J., \& Black, W. C. (2010). Multivariate data analysis: A global perspective (Vol. 7). Pearson Prentice Hall.

Halama, P., Kohút, M., Soto, C. J., \& John, O. P. (2020). Slovak adaptation of the Big Five Inventory (BFI-2): Psychometric properties and initial validation. Studia Psychologica, 62(1), 74-87. https://doi.org/10.31577/sp.2020.01.792

John, O. P., Naumann, L. P., \& Soto, C. J. (2008). Paradigm shift to the integrative Big-Five trait taxonomy: History, measurement, and conceptual issues. Dalam O. P. John, R. W. Robins, \& L. A. Pervin (Eds.), Handbook of personality: Theory and research (3rd ed., hlm. 114-158). Guilford Press.

MacCann, C., Duckworth, A. L., \& Roberts, R. D. (2009). Empirical identification of the major facets of conscientiousness. Learning and Individual Differences, 19(4), 451-458. http://dx.doi.org/10.1016/j.lindif.2009.03.007

Neuman, W. L., \& Neuman, L. W. (2014). Social research methods: qualitative and quantitative approaches. Pearson Education Limited.

Ramdhani, N. (2012). Adaptasi bahasa dan budaya dari skala kepribadian Big Five. Jurnal Psikologi, 39(2), 189-205. https://doi.org/10.22146/jpsi.6986

Rammstedt, B., Danner, D., Soto, C. J., \& John, O. P. (2020). Validation of the short and extra-short forms of the Big Five Inventory-2 (BFI-2) and their German adaptations. European Journal of Psychological Assessment, 36(1), 149-161. https://doi.org/10.1027/1015-5759/a000481

Schmitt, D. P., Allik, J., McCrae, R. R., Benet-Martínez, V., Alcalay, L., Ault, L., Austers, I., Bennett, K. L., Bianchi, G., Boholst, F., Borg Cunene, M. A., Braeckman, J., Brained Jr., E. G., Timmermans, B., Vanhoomissen, T., \& Van Overwalle, F. (2007). The geographic distribution of Big Five personality traits: Patterns and profiles of human self-description across 56 nations. Journal of Cross-Cultural Psychology, 38(2), 173-212. https://doi.org/10.1177/0022022106297299

Shchebetenko, S., Kalugin, A. Y., Mishkevich, A. M., Soto, C. J., \& John, O. P. (2020). Measurement invariance and sex and age differences of the Big Five Inventory-2: Evidence from the Russian version. Assessment, 27(3), 472-486. https://doi.org/10.1177/1073191119860901

Soto, C. J., \& John, O. P. (2017). The next Big Five Inventory (BFI-2): Developing and assessing a hierarchical model with 15 facets to enhance bandwidth, fidelity, and predictive power. Journal of Personality and Social Psychology, 113(1), 117-143. https://doi.org/10.1037/pspp0000096 
Soto, C. J. (2021a). The Big Five Inventory-2 (BFI-2). http://www.colby.edu/psych/personality-lab/

Soto, C. J. (2021b). Translation of The BFI-2: BFI-2 Indonesian self-report form and scoring key. https://www.colby.edu/psych/wp-content/uploads/sites/50/2021/10/bfi2-formindonesian.pdf

Usslepp, N., Hübner, N., Stoll, G., Spengler, M., Trautwein, U., \& Nagengast, B. (2020). RIASEC interests and the Big Five personality traits matter for life success—But do they already matter for educational track choices?. Journal of Personality, 88(5), 1007-1024. https://doi.org/10.1111/jopy.12547

Vedel, A., Wellnitz, K. B., Ludeke, S., Soto, C. J., John, O. P., \& Andersen, S. C. (2021). Development and validation of the Danish Big Five Inventory-2: Domain- and facet-level structure, construct validity, and reliability. European Journal of Psychological Assessment, 37(1), 42-51. https://doi.org/10.1027/1015-5759/a000570

Zhang, B., Li, Y. M., Li, J., Luo, J., Ye, Y., Yin, L., Chen, Z., Soto, C. J., \& John, O. P. (2021). The Big Five Inventory-2 in China: A comprehensive psychometric evaluation in four diverse samples. Assessment. Advanced online publication. https://doi.org/10.1177/10731911211008245 
Lampiran 1.

Blueprint BFI-2 (Daftar lengkap 60 butir BFI-2 dalam Bahasa Indonesia dapat diakses pada https://www.colby.edu/psych/wp-content/uploads/sites/50/2021/10/bfi2-form-indonesian.pdf)

\begin{tabular}{|c|c|c|c|c|}
\hline \multirow{2}{*}{ Faset } & \multirow{2}{*}{ Indikator } & \multicolumn{2}{|c|}{ Butir } & \multirow{2}{*}{$\mathbf{N}$} \\
\hline & & $\mathbf{F}$ & $\mathbf{U F} / \mathbf{r}$ & \\
\hline \multicolumn{5}{|c|}{ Keterbukaan Pemikiran (Open Mindedness) } \\
\hline $\begin{array}{l}\text { Ketertarikan pada seni dan } \\
\text { keindahan } \\
\text { (Aesthetic sensitivity) }\end{array}$ & $\begin{array}{l}\text { Kepekaan terhadap estetika, minat artistik, dan } \\
\text { apresiasi keindahan. }\end{array}$ & 20,35 & 5,50 & \\
\hline $\begin{array}{l}\text { Keingintahuan intelektual } \\
\text { (Intellectual curiousity) }\end{array}$ & $\begin{array}{l}\text { Keingintahuan intelektual, minat yang lebih terhadap } \\
\text { intelektual, dan kenikmatan (kenyamanan) dalam } \\
\text { berpikir. }\end{array}$ & 10,40 & 25,55 & 12 \\
\hline $\begin{array}{c}\text { Imajinasi Kreatif } \\
\text { (Creative imagination) }\end{array}$ & $\begin{array}{l}\text { Kapasitas untuk menghasilkan ide atau solusi baru dan } \\
\text { berguna untuk penyelesaian masalah. }\end{array}$ & 15,60 & 30,45 & \\
\hline
\end{tabular}

\section{\begin{tabular}{cc} 
(Creative imagination) & berguna untuk penyelesaian masalah. \\
\hline Kehati-hatian (Conscientiousness)
\end{tabular}}

$\begin{array}{llll}\text { Keteraturan } & \text { Preferensi pada tugas, kerapian, dan kemauan untuk } & \text { 18, 33 } & \text { 3,48 } \\ \text { (Organization) } & \begin{array}{l}\text { menginvestasikan waktu serta tenaga. } \\ \text { Produktivitas, etos kerja, dan ketekunan dalam }\end{array} & \text { 38, 53 } & \text { 8, 23 }\end{array}$

Produktivitas mengejar tujuan yang mengarah pada penyelesaian

(Productiveness) tugas secara efisien dan efektif (lawan dari penundaan).

Tanggung jawab, komitmen untuk memenuhi tugas, 13, $43 \quad 28,58$

Tanggung jawab dan kewajiban (faset ini memiliki karakteristik

(Responsibility) prososial yang membedakannya dengan dimensi kesetujuan, terutama faset penghormatan).

\begin{tabular}{|c|c|c|c|c|}
\hline \multicolumn{5}{|c|}{ Kesukaan terhadap hal di luar diri (Extraversion) } \\
\hline $\begin{array}{l}\text { Keramahan } \\
\text { (Sociability) }\end{array}$ & $\begin{array}{l}\text { Keinginan untuk melakukan pendekatan sosial dan } \\
\text { terlibat dengan orang lain (termasuk orang asing). }\end{array}$ & 1,46 & 16,31 & \\
\hline $\begin{array}{c}\text { Ketegasan } \\
\text { (Assertiveness) }\end{array}$ & $\begin{array}{l}\text { Kesediaan untuk mengungkapkan pendapat pribadi } \\
\text { dan menggunakan pengaruh sosial. }\end{array}$ & 6,21 & 36,51 & 12 \\
\hline $\begin{array}{l}\text { Semangat } \\
\text { (Energy level) }\end{array}$ & $\begin{array}{l}\text { Tingkat aktivitas fisik dan emosi yang terangsang } \\
\text { secara positif. }\end{array}$ & 41,56 & 11,26 & \\
\hline \multicolumn{5}{|c|}{ Kesetujuan (Agreeableness) } \\
\hline $\begin{array}{l}\text { Belas kasihan } \\
\text { (Compassion) }\end{array}$ & $\begin{array}{l}\text { Sifat welas asih, perhatian emosional aktif untuk } \\
\text { kesejahteraan orang lain, dan ekspresi perilaku dari } \\
\text { perhatian ini (misalnya, membantu, peduli). }\end{array}$ & 2,32 & 17,47 & \multirow{3}{*}{12} \\
\hline $\begin{array}{l}\text { Penghormatan } \\
\text { (Respectfulness) }\end{array}$ & $\begin{array}{l}\text { Memperlakukan orang lain dengan memperhatikan } \\
\text { hak dan preferensi mereka yang menyiratkan } \\
\text { pengendalian impuls agresif atau egois. }\end{array}$ & 7,52 & 22,37 & \\
\hline $\begin{array}{l}\text { Kemudahpercayaan } \\
\text { (Trust) }\end{array}$ & $\begin{array}{l}\text { Kemudahpercayaan memegang keyakinan umum yang } \\
\text { positif tentang orang lain yang mendasari } \\
\text { kemudahpercayaan dan pemaaf. }\end{array}$ & 27,57 & 12,42 & \\
\hline \multicolumn{5}{|c|}{ Kenegatifan emosi (Negative emotionality) } \\
\hline $\begin{array}{l}\text { Kecemasan } \\
\text { (Anxiety) }\end{array}$ & $\begin{array}{l}\text { Kecenderungan untuk mengalami ketakutan dan } \\
\text { kecemasan (lawan dari kemampuan mengelola stres } \\
\text { dengan baik). }\end{array}$ & 19,34 & 4,49 & \multirow{3}{*}{12} \\
\hline $\begin{array}{c}\text { Depresi } \\
\text { (Depression) }\end{array}$ & $\begin{array}{l}\text { Kecenderungan untuk mengalami kesedihan dan } \\
\text { depresi, daripada mempertahankan pandangan yang } \\
\text { positif. }\end{array}$ & 39,54 & 9,24 & \\
\hline $\begin{array}{c}\text { Kelabilan emosi } \\
\text { (Emotional volatility) }\end{array}$ & $\begin{array}{l}\text { Frekuensi perubahan suasana hati, menyiratkan sifat } \\
\text { mudah marah dan temperamen buruk. }\end{array}$ & 14,59 & 29,44 & \\
\hline & Total & 30 & 30 & 60 \\
\hline
\end{tabular}


Lampiran 2.

Blueprint BFI-1

\begin{tabular}{|c|c|c|c|}
\hline \multirow{2}{*}{ Indikator } & \multicolumn{2}{|c|}{ Butir } & \multirow{2}{*}{$N$} \\
\hline & $\mathbf{F}$ & UF & \\
\hline \multicolumn{4}{|l|}{ Extraversion (Ekstraversi) } \\
\hline $\begin{array}{l}\text { Energik, berorientasi terhadap dunia sosial dan material,mencakup } \\
\text { sifat-sifat seperti kemampuan bersosialisasi, aktif, tegasan, dan emosi } \\
\text { positif. }\end{array}$ & $\begin{array}{c}1,11,16 \\
26,36\end{array}$ & $6,21,31$ & 8 \\
\hline \multicolumn{4}{|l|}{ Agreeableness (Kesetujuan) } \\
\hline $\begin{array}{l}\text { Mencakup sifat-sifat seperti altruisme, kelembutan hati, } \\
\text { kemudahpercayaan, dan kesopanan. Menekankan kualitas baik orang } \\
\text { lain saat membicarakannya, memahami perasaan orang lain dengan } \\
\text { baik. }\end{array}$ & $\begin{array}{c}7,17,22 \\
32,42\end{array}$ & $2,12,27,37$ & 9 \\
\hline
\end{tabular}

\section{Conscientiousness}

Sifat-sifat yang mencerminkan perencanaan terhadap penyelesaian tugas, mengikuti norma atau aturan dan merencanakan, mengatur, dan memprioritaskan tugas. Kecenderungan merencanakan tujuan

$3,13,28$

33,38

$8,18,23,43$

9

\section{Neuroticism (Neurotisisme)}

Lawan dari kestabilan emosi, kecenderungan merasakan emosi 4, 14, 19,

negatif, seperti perasaan cemas, gugup, sedih, dan tegang.

29,39

$9,24,34$

8

\section{Openness (Keterbukaan)}

Sifat-sifat yang menggambarkan keluasan, kedalaman, orisinalitas, 5, 10, 15, 20, dan kompleksitas berpikir.

$5,10,15,20$
$25,30,40,44$

35,41

10 